\title{
Exploring the Clinical Utility of Pancreatic Cancer Circulating Tumor Cells
}

\author{
Dannel Yeo 1,2,3 (D), Althea Bastian 1,2,3, Heidi Strauss 1,2,3, Payal Saxena ${ }^{2,4}$, Peter Grimison 2,5 \\ and John E. J. Rasko 1,2,3,6,*(D)
}

1 Li Ka Shing Cell \& Gene Therapy Program, The University of Sydney, Camperdown, NSW 2050, Australia; dannel.yeo@sydney.edu.au (D.Y.); althea.bastian@sydney.edu.au (A.B.); heidi.strauss@sydney.edu.au (H.S.)

2 Faculty of Medicine and Health, The University of Sydney, Camperdown, NSW 2050, Australia; payal.saxena@sydney.edu.au (P.S.); peter.grimison@lh.org.au (P.G.)

3 Cell and Molecular Therapies, Royal Prince Alfred Hospital, Sydney Local Health District (SLHD), Camperdown, NSW 2050, Australia

4 Division of Gastroenterology, Department of Medicine, Royal Prince Alfred Hospital, Sydney Local Health District, Camperdown, NSW 2050, Australia

5 Medical Oncology, Chris O’Brien Lifehouse, Camperdown, NSW 2050, Australia

6 Gene and Stem Cell Therapy Program, Centenary Institute, The University of Sydney, Camperdown, NSW 2050, Australia

* Correspondence: j.rasko@centenary.org.au; Tel.: +61-295-656-160

Citation: Yeo, D.; Bastian, A.; Strauss, H.; Saxena, P.; Grimison, P.; Rasko, J.E.J. Exploring the Clinical Utility of Pancreatic Cancer Circulating Tumor Cells. Int. J. Mol. Sci. 2022, 23, 1671. https://doi.org/10.3390/ ijms23031671

Academic Editor: Ewa

A. Grzybowska

Received: 29 December 2021

Accepted: 28 January 2022

Published: 31 January 2022

Publisher's Note: MDPI stays neutral with regard to jurisdictional claims in published maps and institutional affiliations.

Copyright: (c) 2022 by the authors. Licensee MDPI, Basel, Switzerland. This article is an open access article distributed under the terms and conditions of the Creative Commons Attribution (CC BY) license (https:// creativecommons.org/licenses/by/ $4.0 /)$.

\begin{abstract}
Pancreatic ductal adenocarcinoma (PDAC) is the most frequent pancreatic cancer type, characterized by a dismal prognosis due to late diagnosis, frequent metastases, and limited therapeutic response to standard chemotherapy. Circulating tumor cells (CTCs) are a rare subset of tumor cells found in the blood of cancer patients. CTCs has the potential utility for screening, early and definitive diagnosis, prognostic and predictive assessment, and offers the potential for personalized management. However, a gold-standard CTC detection and enrichment method remains elusive, hindering comprehensive comparisons between studies. In this review, we summarize data regarding the utility of CTCs at different stages of PDAC from early to metastatic disease and discuss the molecular profiling and culture of CTCs. The characterization of CTCs brings us closer to defining the specific CTC subpopulation responsible for metastasis with the potential to uncover new therapies and more effective management options for PDAC.
\end{abstract}

Keywords: liquid biopsy; biomarker; prognosis; screening; stem cell; organoids; precision medicine; personalized medicine

\section{Introduction}

Over recent decades, advances in cancer detection, monitoring, and management have dramatically improved the survival rates and quality of life in cancer patients. Unfortunately, pancreatic cancer has not shared these improvements with the 5-year survival rate remaining below $10 \%$ [1]. In 2021, it is estimated that there will be over 60,000 new cases and over 48,000 deaths making it the fourth most common cause of cancer-related deaths in the United States of America [2]. Based on current trends, it is expected to become the second leading cause of cancer-related death by 2030 [3].

Pancreatic ductal adenocarcinoma (PDAC) accounts for over $90 \%$ of all pancreatic cancers. Many factors contribute to PDAC's high mortality rate and poor prognosis. PDAC is generally asymptomatic in its early stages resulting in the majority of patients diagnosed with late-stage disease. Surgical resection remains the only potentially curative treatment option for PDAC patients, however less than $20 \%$ are suitable at diagnosis due to metastatic disease [4]. Even amongst suitable recipients, the 1-year survival rate following surgery is $20 \%$ with almost $80 \%$ of these patients developing recurrence [5]. Systemic chemotherapy (FOLFIRINOX: combination of folinic acid, fluorouracil (5-FU), irinotecan, and oxaliplatin; 
or combination of gemcitabine and nab-paclitaxel) is commonly used as first-line treatment for metastatic disease [6,7]. However, response rates and survival improvements are limited, and chemotherapy-related toxicities reduce their wider utility [8,9]. Although CA19-9 (carbohydrate antigen 19-9) is widely used as a serological marker in monitoring PDAC progression and response as a tumor burden marker, it is only elevated in $80 \%$ of cases and does not assist in predicting progression or response [10]. Hence, there is a need for superior biomarkers which can help stratify patients based on their risk of progression, recurrence and chemotherapy response, thereby enabling optimal and effective treatment management for patients.

\section{Liquid Biopsies in PDAC}

Tissue sampling for diagnosis is commonly carried out by endoscopic ultrasound (EUS)-guided biopsy [11,12]. Percutaneous radiologically-guided biopsy and open surgical biopsy are other biopsy procedures but are generally uncommon. EUS-guided biopsy requires anesthesia and carries a small risk of adverse events, so is therefore not suitable for repeated sampling $[13,14]$. Additionally, despite the high sensitivity of EUS-guided biopsies, the heterogeneity of tumor tissue and presence of abundant tumor stroma can impair the negative predictive value which can range from 40-70\% [11,15,16].

In contrast to tissue biopsies, sampling peripheral blood is a simple, minimally invasive routine procedure. The detection of biomarkers within the peripheral blood, termed "liquid biopsy", has been increasingly examined for a range of potential applications spanning cancer diagnosis to treatment [17]. The ease and minimal risk of peripheral blood collection allows for multiple samples to be collected from a patient, enabling longitudinal, long-term disease surveillance and monitoring. However, in order to fully utilize the potential of liquid biopsies, reliable blood-based biomarkers must first be identified and validated.

To date, CA19-9 and CEA (carcinoembryonic antigen) are the only routinely used clinical blood-based biomarkers for PDAC, with high levels indicative of advanced tumor stage $[18,19]$. While CA19-9 and CEA both have high specificity in PDAC (0.82 and 0.73, respectively) their sensitivity is limited ( 0.43 and 0.78 , respectively) [19]. CA19-9 also has a number of caveats regarding its use, including being also elevated in benign disease and not being expressed in up to $10 \%$ of the Caucasian population who do not express the Lewis antigen [20]. Due to the potential of liquid biopsy biomarkers, efforts to identify other potential blood-based biomarkers alone or in conjunction with CA19-9/CEA have been undertaken. These include circulating tumor DNA (ctDNA) [21,22], exosomes [23], metabolites [24], non-coding RNA [25], and circulating tumor cells (CTCs) [26,27]. These biomarkers each have their own advantages and disadvantages in their application as a cancer diagnostic, prognostic and predictive biomarker.

Circulating tumor DNA (ctDNA) represents a subset of cell-free DNA (cfDNA). Marked variations in the amount of cfDNA has been detected in healthy individuals and is associated with a range of conditions such as inflammation and tissue damage during intense physical activity [28,29]. ctDNA has a short half-life which can result in low yield and susceptibility to degradation during processing or inappropriate sample handling $[17,30]$. Sensitivity for KRAS-specific ctDNA has been reported in $27 \%$ to $81 \%$ of PDAC patients and the identification of targetable mutations is generally limited to patients with high ctDNA levels [30,31]. Thus far, ctDNA detection has been shown to predict PDAC recurrence, presence of minimal residual disease, and correlates with patient survival [32-34].

Exosomes are small extracellular vesicles with sizes between $30-150 \mathrm{~nm}$ that are secreted by all cell types and are responsible for intercell communication [35]. Although research into cancer exosomes commenced relatively recently, there has been much excitement. Similar to cfDNA, sensitivity in cancer-specific exosomes has been reported to range widely in PDAC patients, where $50 \%$ to $100 \%$ has been reported [23]. Exosomal markers have been identified for PDAC diagnosis, recurrence, and prognosis including miR-21, 
miR-451, miR-196a, miR-1246, and glypican-1 [36]. Isolation methods for exosomes, such as ultracentrifugation are currently inefficient and inconsistent, leading to difficulties in their characterization [37]. However, their clinical applicability as a biomarker in PDAC will continue to grow as well as their therapeutic applications as a delivery system $[38,39]$.

CTCs are a rare subset of tumor cells found in the blood of solid tumor patients, functioning as the "seeds" of metastasis. They offer potential advantages over competing liquid biopsy biomarkers, particularly the ability to undertake downstream functional characterization. CTCs provide multiple opportunities to determine their phenotypic origins by way of surface-antigen identification and single-cell genomic and gene expression analysis [40,41]. The isolation of viable CTCs provides the added advantage of allowing further culturing and characterization of live cells by ex vivo culture or animal xenografts, providing a deeper understanding of an individual's tumor characteristics [42,43]. This capacity goes beyond solely prognostic and diagnostic purposes and may help direct targeted, personalized treatments. This is of particular significance in PDAC where there are limited treatments available and a targeted approach may improve outcomes. Targeted therapy in PDAC has been shown to result in longer median survival where $26 \%$ of PDAC patients were found to harbor an actionable genomic alteration [44,45]. While genomic and transcriptomic analysis of tissue biopsy samples have been undertaken, there are limitations in the quantity of material obtained, heterogeneity of tumor cells, and contamination by stromal cells and other tissues. However, it is still unknown how representative CTCs are (this will be discussed in more detail in the "CTC Characterization" section).

CTCs may be a more accessible equivalent to tissue biopsy sampling. There is also the opportunity to monitor changes in tumor biology over time such as in response to therapy. Hence, the detection and isolation of CTCs may be a crucial tool to complement other biomarkers in order to personalize PDAC treatment.

\section{Circulating Tumor Cells}

CTCs are malignant cells present in the bloodstream and are understood to be the "seeds" of metastasis. CTCs are shed from the primary tumor and travel through the vascular system to a secondary site, where given the correct environment, they will settle and multiply, thereby forming a metastatic tumor (Figure 1) [46]. CTCs have been studied extensively in breast, colorectal, and prostate cancer as a non-invasive assessment of disease progression and prognosis [47-49]. In PDAC, studies have largely focused on CTCs' prognostic ability where the presence and number of CTCs has been correlated with worse survival $[27,50]$.

\section{CTC Enrichment and Detection}

CTCs were first discovered in 1869, when Australian physician, Thomas Ashworth, described cells similar to cancer cells from blood drawn from the saphenous vein [51]. However, only recent technological advancements have facilitated detection, enumeration, and isolation of these rare cells in a sensitive and reproducible manner for clinical and research applications. In PDAC, CTC counts have been found to be one of the lowest amongst solid cancers using the CellSearch ${ }^{\circledR}$ CTC detection method [52]. Diverse techniques and technologies developed for CTC enrichment, isolation, and identification from peripheral blood samples have been thoroughly described $[26,27,50,53]$. Broadly, these methods employ strategies based on either the physical properties or surface phenotype of CTCs. These include size and density using filters or microfluidic devices, or detection using immuno-magnetic separation based on surface markers or high-resolution image scanning, in order to distinguish CTCs from erythrocytes and normal nucleated blood cells (Figure 2). 


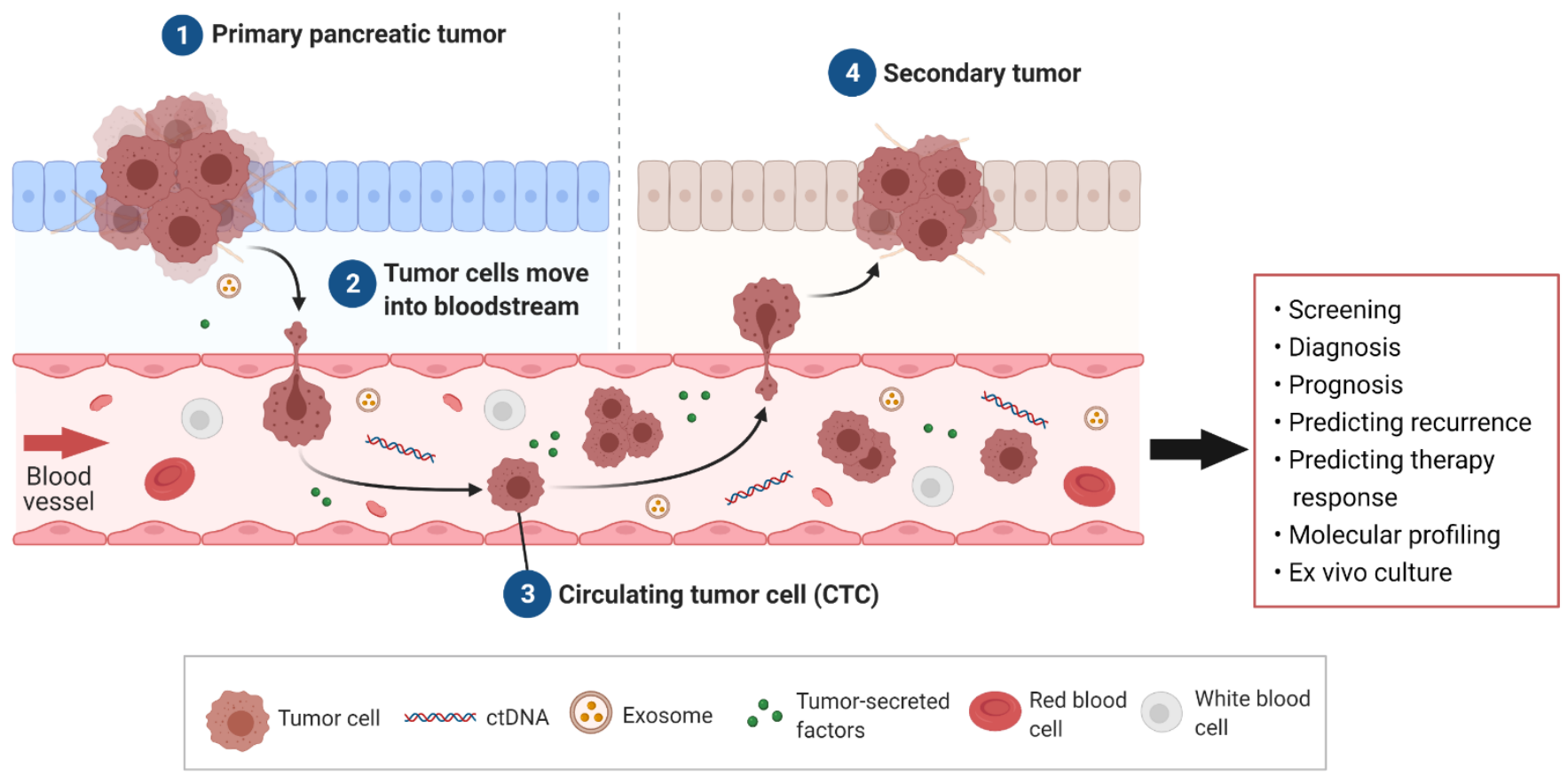

Figure 1. Circulating tumor cells (CTCs) arising in pancreatic ductal adenocarcinoma (PDAC) and their clinical utility. Tumor cells, along with other liquid biopsy biomarkers such as circulating tumor DNA (ctDNA), exosomes, and secreted factors such as metabolites, are secreted into the bloodstream from the PDAC tumor. Tumor cells, termed CTCs, travel through the blood to secondary sites to form metastases. Potential clinical applications of PDAC CTCs include screening, diagnosis, prognosis, predicting recurrence, and therapeutic response as well as insights into an individual's tumor through molecular profiling and culture.

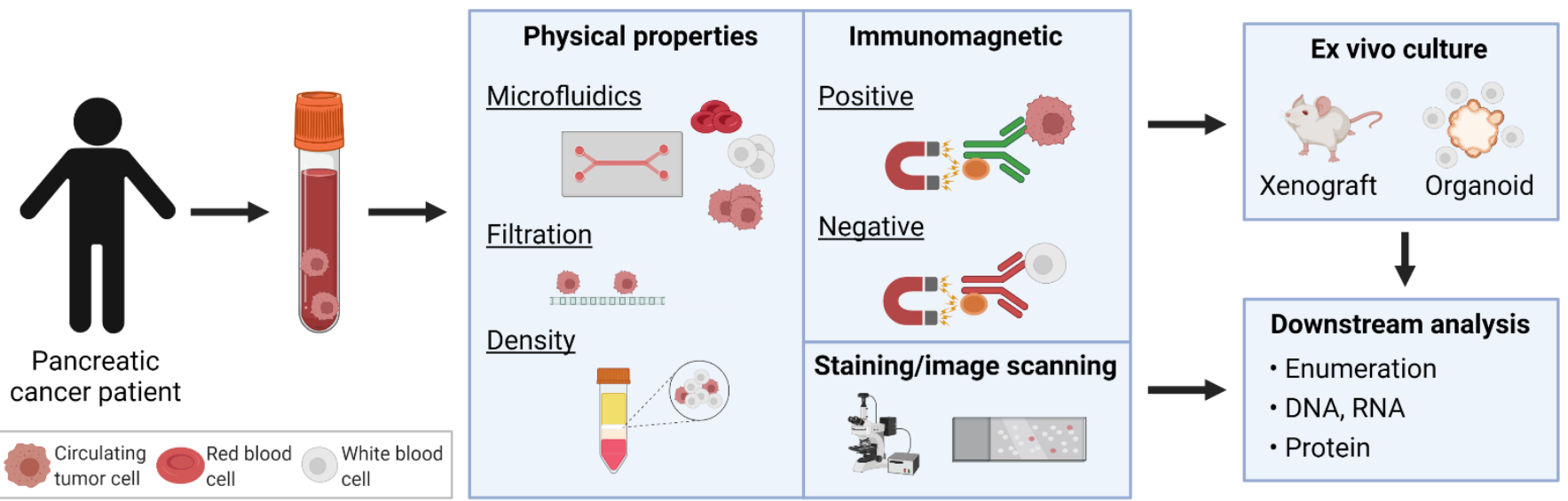

Figure 2. Isolation of circulating tumor cells (CTCs) in pancreatic cancer. Various enrichment and detection methods have been used to identify CTCs. Identified CTCs may be propagated by ex vivo culture through xenografts or organoids, or directly analyzed for enumeration and DNA/RNA/protein profiling.

Density centrifugation was employed in early studies to isolate CTC sased on size and density with generally low detection rates of $24 \%$ to $40 \%$ in PDAC patients [54-56]. Later studies used membrane filtration such as ISET (isolation by size of epithelial tumor cells) [57-59], MetaCell [60], and Screencell [40,61] provided much higher efficiencies from $66 \%$ to $96 \%$ detection amongst PDAC patients. Microfluidic devices, such as the NanoVelcro, have also displayed high detection efficiency of around $75 \%$ in treatmentnaive patients [62,63]. Other microfluidic devices have reached higher than $80 \%$ detection 
rates [64,65]. Recently, SMART-Chip, an automated, modular microfluidic device incorporating impedance and imaging for rapid confirmation of the isolated cells, found CTCs in a PDAC patient as a proof-of-principal study [66]. Unfortunately, the limitation with this strategy of isolation, using their physical property, is that CTCs have been found to be equal or smaller in size to nucleated blood cells (ranging between 4 and $30 \mu \mathrm{m}$ ) so specificity may be low $[67,68]$.

The other common method of isolation is by immuno-magnetic separation via surface tumor antigens, also known as positive selection. The only FDA-approved method of CTC isolation thus far is CellSearch ${ }^{\circledR}$ which utilizes immunomagnetic separation using epithelial markers on CTCs. It is the method which has been tested in the greatest number of studies but has performed relatively poorly with detection rates of $7-48 \%$ across various stages of PDAC (Table 1) [23,52,57,69-71]. A limitation of using epithelial markers is that they can be downregulated or lost as CTCs undergo epithelial-mesenchymal transition (EMT) [31,72]. Furthermore, CTCs are heterogeneous and to date, a universal CTC antigen remains elusive. Thus, another strategy of immunomagnetic separation is by negative selection where white blood cells are depleted. This increases the likelihood of isolating CTCs expressing various antigens however, some loss of CTCs has been noted while achieving $80 \%$ detection efficiency [73]. High resolution image scanning of CTCs is an enrichment-free method to identify CTCs. Fixed blood cells are spread onto slides and stained. CTCs are detected after slide images are analyzed. Two platforms that utilize this method include the RareCyte ${ }^{\circledR}$ platform and Epic CTC platform, however they have, thus far, not been tested in PDAC patients $[74,75]$.

Table 1. Circulating tumor cell (CTC) detection using CellSearch ${ }^{\circledR}$ in peripheral blood samples from patients with pancreatic ductal adenocarcinoma (PDAC).

\begin{tabular}{|c|c|c|c|c|c|}
\hline $\begin{array}{l}\text { Year of } \\
\text { Report }\end{array}$ & $\begin{array}{l}\text { Number of } \\
\text { Patients }\end{array}$ & PDAC Stage & $\begin{array}{l}\text { CTC Detection } \\
\text { (\% Patients) }\end{array}$ & Main Findings & Ref. \\
\hline 2004 & 16 & Advanced & 19 & $\begin{array}{c}\text { CTCs found in various cancers and negligible } \\
\text { in healthy }(0.3 \%)\end{array}$ & [52] \\
\hline 2008 & 26 & All & 42 & CTCs correlated with shorter survival & [76] \\
\hline 2011 & 54 & $\begin{array}{l}\text { Locally advanced } \\
\text { and advanced }\end{array}$ & 40 & CTCs associated with shorter survival & [57] \\
\hline 2013 & 79 & Locally advanced & 11 & $\begin{array}{c}\text { CTCs correlated with poor tumor } \\
\text { differentiation and shorter survival } \\
\text { No correlation between CTCs and survival. }\end{array}$ & [77] \\
\hline 2014 & 20 & Local & 20 & $\begin{array}{c}\text { Portal vein CTCs (detected in } 45 \% \text { ) associated } \\
\text { with liver metastases }\end{array}$ & [78] \\
\hline 2015 & 45 & All & 20 & $\begin{array}{l}\text { CTCs mainly found in advanced disease. CTCs } \\
\text { correlated with shorter survival }\end{array}$ & [79] \\
\hline 2015 & 14 & All & 21.4 & $\begin{array}{l}\text { Portal vein collection using EUS was feasible. } \\
\text { Portal vein CTCs detected in } 100 \% \text { patients }\end{array}$ & [80] \\
\hline 2017 & 65 & Advanced & 32.3 & $\begin{array}{l}\text { CTCs correlated with presence of liver } \\
\text { metastasis and shorter survival }\end{array}$ & [69] \\
\hline 2017 & 48 & Advanced & 48 & $\begin{array}{c}\text { No correlation between CTCs and survival. } \\
\text { MUC1-positive CTCs correlated with } \\
\text { shorter survival }\end{array}$ & [81] \\
\hline 2018 & 20 & Local & 25 & MACS enrichment/Ariol vs CellSearch & [70] \\
\hline 2019 & 22 & Local & 32 & $\begin{array}{c}\text { CTC combined with GPC1-exosomes: } 100 \% \\
\text { sensitivity and } 80 \% \text { specificity for diagnosis. } \\
\text { CTC clusters with GPC1-exosomes correlated } \\
\text { with shorter survival }\end{array}$ & [23] \\
\hline 2021 & 98 & Local & 7.1 & $\begin{array}{c}\text { CTCs correlated with recurrence and } \\
\text { shorter survival }\end{array}$ & [71] \\
\hline
\end{tabular}

A gold-standard CTC detection method remains elusive, although there are many emerging methods and technologies. One of the main reasons is the heterogeneous nature of CTCs. Each CTC detection technology exhibits merits and limitations, but these discrep- 
ancies make comparative studies difficult and consequently rarely undertaken. This has limited the molecular characterization of CTCs where the sub-population of CTCs that cause metastases, if it exists, is yet to be defined. The collection and analysis of CTCs from the portal vein is feasible in PDAC patients. In such cases, there were increased numbers of CTCs compared to peripheral blood $[78,80,82]$. This is consistent with expectations as the portal vein is the draining blood vessel from the pancreas and has not undergone hepatic filtration. However, it involves a more invasive procedure, limiting its applicability. Another consideration is blood collection as this is a crucial first step of the CTC detection workflow. The blood collection tubes used can impact on the number of CTCs detected [83,84]. A method that can reliably detect CTCs with high sensitivity and specificity as well as low user/site variability combined with the ability to undertake single-cell characterization would be useful in both the clinical and research settings.

\section{Clinical Utility of CTCs in PDAC}

\subsection{Diagnosis and Early Detection}

There is currently no established screening test for PDAC in the general population. Most patients with PDAC remain asymptomatic until late-stage disease at which point the tumor is large enough to cause biliary obstruction or invade adjacent nerves and cause pain [85]. PDAC is diagnosed with abdominal imaging (CT scan or MRI) and tissue diagnosis pathologically confirmed with a EUS-guided biopsy. Benign or premalignant pancreatic lesions (such as pancreatic intraepithelial neoplasms (PanINs), intraductal papillary mucinous neoplasms (IPMN), mucinous cystic neoplasms (MCN), and other cystic lesions) are a frequent incidental finding and are common in the general population $(2.6 \%$ for $>2 \mathrm{~mm}$ lesion) [86]. These are often detected during transabdominal imaging of asymptomatic individuals during investigation of unrelated symptoms or conditions. Surveying these pancreatic lesions with a high risk of malignant transformation, using a combination of $\mathrm{CT}$, MRI, and EUS, is recommended to enable the early detection of PDAC [87]. Another subset of patients at increased risk of developing PDAC are "high risk individuals" that have a strong family history of PDAC or who carry genetic abnormalities that predisposition them to PDAC (Peutz Jeghers syndrome, STK11, p16/CDKN2A, BRCA1, BRCA2, ATM, PALB2, Lynch syndrome, and hereditary pancreatitis (PRSS1, PRSS2, and CTRC)). The Cancer of the Pancreas Screening (CAPS) program screens these patients through an annual EUS procedure $[88,89]$. Current screening and diagnosis involve complex imaging modalities and procedures and so a complementary or more accurate and easily accessible liquid biopsy test could drastically improve patient outcomes in PDAC.

Considering metastasis is often thought of as occurring late in cancer progression, CTCs were not expected to be detected in premalignant and early stages of PDAC. However, a study in mice detected circulating epithelial cells (CECs) of pancreatic origin in the premalignant stages of a genetically-engineered pancreatic cancer mouse model [90]. This led to a pilot study by the same group in patients with IPMNs in which CECs were detected in 33\% (7 of the 21) of IPMN patients without clinical diagnosis of cancer [91]. Studies have identified CECs in up to $88 \%$ of patients with precursor lesions, predominantly IPMN, undergoing surgical resection (Table 2) [92-94]. In one of the studies, CECs were found in all patients with high-grade dysplasia indicating its potential to stratify high-grade to low-grade IPMN and other benign cysts [93]. Thus, these pilot studies demonstrate that CECs can be detected in premalignant stages of PDAC, but larger confirmatory studies are required. There is also limited information concerning the phenotypic characterization of detected CECs and their propensity to "seed" at metastatic sites is unknown. Characterizing CECs could provide valuable insights into PDAC development and, if they are found to be the "seeds" of metastases, would shift the current paradigm of metastasis in PDAC. Due to the low number of circulating cells in the early stages of PDAC, technologies to extract and process large volumes of blood, such as leukapheresis, have being developed and would be ideal in this early stage setting but have not been validated [95]. 
Table 2. Circulating epithelial cell (CEC) detection in benign or premalignant pancreatic lesions.

\begin{tabular}{|c|c|c|c|c|c|c|}
\hline $\begin{array}{l}\text { Year of } \\
\text { Report }\end{array}$ & $\begin{array}{l}\text { Number of } \\
\text { Patients }\end{array}$ & CEC Method & $\begin{array}{l}\text { CEC Method } \\
\text { Type }\end{array}$ & $\begin{array}{l}\text { CEC } \\
\text { Detection } \\
\text { Rates (\% } \\
\text { Patients) }\end{array}$ & Comments & Ref. \\
\hline 2014 & $\begin{array}{l}\text { Cystic lesion: } \\
21 \\
\text { Healthy: } 19\end{array}$ & GEDI & Microfluidic & $\begin{array}{l}\text { Cystic lesion: } \\
33 \\
\text { Healthy: } 0\end{array}$ & $\begin{array}{l}\text { Patients with cystic lesions and no } \\
\text { clinical diagnosis of cancer (Sendai } \\
\text { criteria negative) }\end{array}$ & [91] \\
\hline 2015 & $\begin{array}{l}\text { IPMN: } 21 \\
\text { Healthy: } 9\end{array}$ & Screencell & $\begin{array}{l}\text { Filtration } \\
\text { device }\end{array}$ & $\begin{array}{l}\text { IPMN: } 49 \\
\text { Healthy: } 0\end{array}$ & $\begin{array}{l}\text { CEC detection rates were similar in } \\
\text { patients with benign }(46 \%), \\
\text { premalignant }(49 \%) \text {, and malignant } \\
(49 \%) \text { lesions }\end{array}$ & [92] \\
\hline 2016 & $\begin{array}{l}\text { IPMN: } 15 \\
\text { MCN: } 2\end{array}$ & NanoVelcro & Microfluidic & $\begin{array}{l}\text { IPMN: } 0 \\
\text { MCN: } 0\end{array}$ & $\begin{array}{c}\text { Median CTC count in their PDAC } \\
\text { cohort was } 2\end{array}$ & [62] \\
\hline 2017 & $\begin{array}{l}\text { IPMN: } 16 \\
\text { MCN: } 1 \\
\text { Healthy: } 9\end{array}$ & Screencell & $\begin{array}{l}\text { Filtration } \\
\text { device }\end{array}$ & $\begin{array}{l}\text { IPMN: } 75 \\
\text { MCN: } 100 \\
\text { Healthy: } 0\end{array}$ & $\begin{array}{l}\text { No morphologic differences between } \\
\text { cells from different pancreatic diseases }\end{array}$ & [96] \\
\hline 2017 & $\begin{array}{l}\text { IPMN: } 19 \\
\text { MCN: } 1\end{array}$ & ISET & $\begin{array}{l}\text { Filtration } \\
\text { device }\end{array}$ & $\begin{array}{l}\text { IPMN: } 58 \\
\text { MCN: } 0\end{array}$ & $\begin{array}{l}\text { More likely found in patients with } \\
\text { IPMNs with high-grade dysplasia }\end{array}$ & [93] \\
\hline 2018 & $\begin{array}{l}\text { IPMN: } 20 \\
\text { Healthy: } 11\end{array}$ & $\begin{array}{l}\text { CTC-iChip } \\
\text { (followed by } \\
\text { IF/RNA-ISH) }\end{array}$ & Microfluidic & IPMN: 88 & $\begin{array}{c}\text { Detected CECs likely from pancreatic } \\
\text { lesions by RNA-seq }\end{array}$ & [94] \\
\hline 2018 & $\begin{array}{l}\text { IPMN: } 13 \\
\text { MCN: } 2 \\
\text { PanIN: } 2\end{array}$ & NanoVelcro & Microfluidic & $\begin{array}{l}\text { IPMN: } 0 \\
\text { MCN: } 0 \\
\text { PanIN: } 0\end{array}$ & $\begin{array}{l}\text { Median CTC count in the PDAC cohort } \\
\text { was } 2\end{array}$ & [63] \\
\hline 2019 & $\begin{array}{l}\text { IPMN: } 16 \\
\text { Healthy: } 30\end{array}$ & $\begin{array}{l}\text { CytoQuest }^{\mathrm{TM}} \\
\text { CR } \\
\text { (Vimentin+) }\end{array}$ & Microfluidic & $\begin{array}{l}\text { IPMN: } 25 \\
\text { Healthy: } 0\end{array}$ & $\begin{array}{l}\text { Using a cut-off value of } 2 \text { cells } / 4 \mathrm{~mL} \\
\text { of blood }\end{array}$ & [97] \\
\hline
\end{tabular}

CECs may identify patients earlier than conventional diagnosis as recently shown where the PanSeer assay, which detects ctDNA, was able to identify cancer patients 4 years prior to conventional diagnosis [98]. However, longitudinal CEC studies with adequate follow-up are currently lacking. Genetic studies with mathematical modeling in PDAC have suggested that the window of opportunity to diagnose and treat precursor lesions is almost 12 years, illustrating a potentially wide opportunity for early detection and preventative management [99]. Thus, screening for CECs could be incorporated to patients undergoing surveillance for benign or premalignant pancreatic lesions as well as "high risk individuals" in the CAPS program. Studies may be underway already where the current CAPS program, CAPS5 (NCT02000089), includes as part of their primary outcome, examination of CECs from pancreatic duct fluid.

\subsection{Prognosis and Recurrence}

As with many other solid cancers [100-103], the detection and enumeration of CTCs has clinical utility as a prognostic marker in PDAC. Comprehensive reviews and metaanalyses of up to 19 studies comprising over 1300 PDAC patients have demonstrated that the detection of CTCs correlates with worse progression-free survival and overall survival $[27,104-106]$. This was observed despite the use of a variety of CTC detection methods, illustrating the strong prognostic value of CTCs. Further subset analysis of the studies illustrated both the robust principles underlying CTC hypothesis, and that the prognostic value of CTC enumeration held true for both Asian and Caucasian populations.

Many studies have examined CTCs as a prognostic marker in resectable PDAC patients undergoing surgical resection $[58,59,70,71,107-110]$. CTC detection consistently correlates with early recurrence of disease. The CLUSTER study prospectively collected and evaluated 
CTCs using the ISET device longitudinally in one of the largest reported studies comprising over 200 patients with presumed PDAC [107]. Analysis of retrospective data found CTC enumeration preoperatively could predict early recurrence within 12 months after surgery in neoadjuvant-treated and first-line resected patients. Overall survival was significantly longer in the neoadjuvant-treated patients who lacked detectable CTCs [107]. Hence, CTCs could be used to stratify patients at the minimal residual disease setting following surgical resection who may have an increased risk of recurrence and benefit from earlier or more intensive treatments with investigational agents, although prospective randomized clinical trials are lacking.

Pre-operative CTCs could also be used to identify patients who are eligible for surgery. One study of 53 patients found that elevated pre-operative CTC counts ( $\geq 3$ CTCs $/ 4 \mathrm{~mL}$ using the NanoVelcro microfluidic device) was able to significantly distinguish between patients with occult metastatic disease and those with potentially curable, localized tumors with $85 \%$ sensitivity and $80 \%$ specificity [63].

A recent study examined circulating stromal cells, cancer-associated macrophage-like cells (CAMLs) in addition to CTCs in PDAC patients using CellSieve, a microfiltration device that isolates cells based on size exclusion [111]. Although 23\% of PDAC patients had CTCs, $95 \%$ of patients had CAMLs. Both the number and size of CAMLs significantly correlated with advanced pathological stage and progression-free survival. No CAMLs were identified in the healthy control group.

\subsection{Chemotherapy Response}

The ability of CTCs to predict response to chemotherapy in PDAC patients in the neoadjuvant and advanced settings is less clear. In a study with 57 patients undergoing surgery, those who had undergone neoadjuvant therapy had significantly lower median CTC counts compared to up-front chemo-naïve patients at time of surgery [107]. However, this pattern was not observed in a different study where no difference was observed in the 16 patients who had undergone neoadjuvant therapy [58]. There is difficulty in drawing firm conclusions from these studies as there are a number of biases such as patient selection, resectability criteria, and chemotherapy used. This is emphasized by the fact that preoperative clinical factors do not predict resectability in PDAC patients undergoing neoadjuvant chemotherapy [112].

One study showed that stable or decreased CTC numbers were detected in advanced patients with stable disease or who responded to chemotherapy [97]. This study used vimentin to enrich and detect mesenchymal CTCs using a microfluidic device in 100 PDAC patients. However, it should be noted that two patients with progressive disease also had low CTCs and minimal increases in CTCs over time. This illustrates low specificity and the bias of using a mesenchymal-only method for CTC detection. Another study found that the absence of CTCs (detected by CellSearch ${ }^{\circledR}$ ) at 3 months after chemotherapy correlated with better overall survival [69]. In summary, it is difficult to conclude whether CTCs are able to predict chemotherapy response due to variations across studies with the use of different staging criteria, chemotherapy used, and method of CTC identification. Considering that the majority of PDAC patients are diagnosed with advanced disease and are given first line chemotherapy of either FOLFIRINOX or gemcitabine with nab-paclitaxel, CTCs could be used to identify which chemotherapy option would be best for the individual and, also, to identify a given patient's eligibility to receive investigational therapies.

\section{CTC Characterization}

\subsection{CTC Phenotype}

The major advantage of CTCs in comparison to other liquid biopsy techniques is the detection of the whole tumor cell. This allows for the identification of other markers and characterization beyond the enumeration of CTCs. Most studies have focused on characterizing the metastatic ability of CTCs using cancer stem cell markers and mesenchymal markers, as it is thought that this will determine the subpopulation that is responsible 
for metastasis. Identifying this subpopulation would be clinically useful for monitoring patients and for targeting to prevent further cancer spread. However, such a CTC subpopulation remains elusive. Studies, thus far, have limited participant numbers and comparisons between studies is difficult. Often studies reach conflicting conclusions due to the CTC methods used resulting in the potential identification of different CTC phenotypes. A recently published experimental mouse model allowed for the examination of CTC dynamics such as shedding and propensity to metastasize, to enhance the characterization of CTCs [113].

The mesenchymal phenotype of CTCs correlates with disease progression in diverse cancers such as lung and breast cancer [114-116]. Conversely, an increased proportion of epithelial CTCs correlates with treatment response. This highlights the bias that may occur with epithelial- and mesenchymal-only detection methods and illustrates the need to phenotype and characterize CTCs rather than relying solely on their enumeration. This was shown in a recent study where CTCs were isolated using an epitope-independent approach involving microfluidics-based dielectrophoresis enrichment followed by a multiplexed immunostaining assay to identify epithelial, mesenchymal, partial-EMT (expressing both epithelial and mesenchymal markers), and stem cell-like CTCs [117]. The study found that total CTC counts did not correlate with any clinicopathological variables. However, there was a positive correlation between the proportion of partial-EMT cells and advanced disease, worse progression-free and overall survival, and earlier recurrence after resection. Another study also detected CTCs expressing both epithelial and mesenchymal markers in $36.4 \%$ of patients but in this case mesenchymal CTCs, and not the partial-EMT CTCs, significantly correlated to advanced stage and presence of distant metastasis [118].

Cancer stem cell markers have been examined to identify stem cell-like CTCs. Not only could these markers help identify the subpopulation of cells that cause metastasis, there is also evidence that the presence of these cells in the primary tissue correlates to resistance to treatment. For example, CD133, CXCR4, and ALDH1 expression has been shown to play a role in resistance to chemotherapy [119,120]. A number of stem cell markers have been identified in PDAC such as CD44, CD24, c-met, ALDH, CD133, and RORr, however, to date, CTC studies are limited to only one of these markers at a time [121]. Gene expression analysis of CTCs found that high expression of ALCAM, POU5F1B, and SMO were predictive of poor overall survival [41]. After chemotherapy, CTCs express higher expression of stemness and pluripotency genes (CD44, ALCAM, EPCAM, NOTCH1, POU5F1B, and PTCH1) or cancer stem cell drivers (VEGFB and STAT3). Examination of CTCs could also lead to the identification of novel drivers of metastases such as the LIN28B gene which was found to be prognostic [122]. Another study found that the cancer stem cell marker, CD133, helped identify a small subset of patients with progressive disease potentially illustrating progressive clonal treatment resistance [65]. However, a different study examining CD133+ CTCs did not find any predictive or prognostic value in the local or advanced disease settings [117].

CTC clusters, or circulating tumor microemboli, have been shown to have greater metastatic potential than single CTCs [123]. CTC clusters have a survival advantage in the circulation, protecting the tumor cells from apoptosis, shear stress, and immune response [124]. Neutrophils in breast cancer and platelets in PDAC has been found to chaperone CTC clusters $[125,126]$. As such, EpCAM-based methods such as CellSearch ${ }^{\circledR}$ may exclude these CTC clusters based on their CD45 expression. CTC clusters have been detected in PDAC patients in several studies $[41,117,125]$. In one study, it was found that the presence of CTC clusters, rather than CTCs, was correlated with reduced overall survival, suggesting its use as a prognostic marker [127]. However, another study did not observe this, and a correlation was not observed between the presence of CTC clusters and patient survival [41]. CTC clusters could be a potential indicator of chemotherapy response [128]. 


\subsection{CTC Genotype}

Genotypic analysis of CTCs has been used to confirm the identity of CTCs in PDAC. This typically involves detecting the presence of the KRAS mutation which is found in close to $90 \%$ of PDAC patients [129]. 100\% concordance for KRAS mutations in CTCs compared to their matched primary tissue was found in 5 PDAC patients [62], 19 PDAC patients [80], and 32 resectable PDAC patients [109]. However, a larger study with 58 patients did find discordance in $42 \%$ of patients where a different KRAS mutation was found compared to their primary tumor [130]. This could represent the natural evolution of the cancer where tumor cells acquired mutations in their secondary sites, heterogeneity within the primary tumor or technical limitations [131]. Hence, using only the KRAS mutation to confirm tumor identity with the primary tissue may not be sufficient, and may require the addition of other genetic mutations such as TP53, SMAD4, and/or CDKN2A which together account for the top four mutations observed in PDAC [129].

Further genotypic characterization of CTCs is currently constrained by the technical limitations of single-cell sequencing in single CTCs. A retrospective study using bulk CTCs found that an increase in SMAD4 expression levels in CTCs was associated with longer progression free survival in advanced patients treated with gemcitabine/nab-paclitaxel [132]. A recent study utilized targeted single cell next-generation sequencing technology without pre-amplification to examine the three major driver genes: KRAS, TP53, and SMAD4 in ISET-enriched single isolated CTCs [133]. In the future, single-cell sequencing may be more widely available for larger targeted genetic panels to determine specific therapies. A retrospective ctDNA study found $48 \%$ of 357 PDAC patients had a therapeutically relevant mutation [134].

Substantial progress has been made using ctDNA for targeted therapies. Some PCRbased single-gene and multigene assays, as well as high-throughput NGS-based multigene tests, have recently received FDA approval [135]. However, no routine test exists in PDAC yet. Although there is concordance between ctDNA and CTC mutations [136], further studies are required to examine if there is additional clinical benefit by examining the CTC genotype for targeted therapy.

\subsection{CTC Culture}

Culturing CTCs will become essential for future drug discovery and targeting metastatic disease. While labor-intensive, this allows for the propagation of CTCs for downstream analysis thereby overcoming the limitations of limited cell numbers. Successful culture of CTCs has been accomplished in very few studies, mainly in prostate, breast, and lung cancer [137-139]. Initial studies used negative selection, namely RosetteSep ${ }^{\mathrm{TM}}$, to deplete CD45-positive leukocytes, leaving untouched CTCs for ex vivo culture. This has been successfully achieved in 6 small-cell lung cancer patients using CTC-derived xenografts [140]. CTCs have also been isolated from the blood of prostate cancer patients and grown as organoids, which are 3D culture systems that self-organize to resemble the tissue of origin [141].

Current evidence indicates that PDAC CTC cultures are possible, however, further investigations are required to determine the correct conditions to establish CTC cultures reliably. One study investigated the use of extracellular matrix microarrays for isolating and culturing CTCs from mice engrafted with primary human PDAC tumors [142]. In another study, generated PDAC CTC organoids required co-culture with immune cells, but could only be propagated for up to 7 days [143]. A more recent study used a CTC organoid fibroblast co-culture system to examine cancer-induced stromal reprogramming of metabolic pathways [144]. Since organoid cultures have previously been generated from hard-to-obtain tissue samples (such as a tissue biopsy [145]), comparisons with matched CTC-derived organoids have not been reported. Such correlations would be clinically useful to determine if CTC-derived organoids could replace the need for tissue biopsies. Finally, CTC-derived organoids could facilitate precision/personalized approaches through drug screening, which are already underway in tissue-derived organoids [146]. 


\section{Conclusions and Future Perspectives}

Obtaining repeated tissue samples from PDAC patients is challenging due to the anatomical position of the pancreas whereby invasive procedures are required such as EUSguided biopsies. Liquid biopsies are minimally invasive and can be easily collected over multiple time-points, enabling longitudinal, long-term disease surveillance and monitoring. Among the liquid biopsies, CTCs allow more in-depth characterization of tumor cells, including multiomic analysis and potential to culture for drug screening, possibly leading to personalized treatments. CTCs may provide a deeper understanding of an individual's tumor characteristics, beyond the prognostic and diagnostic value which current smallscale studies have found in PDAC patients. However, the predictive value of CTCs is yet to be comprehensively investigated in the clinical setting. Large-scale prospective studies with CTC-guided management are needed to validate the clinical potential of CTCs.

Considering that a "window of opportunity" from the earliest genetic alteration in a precursor lesion to the development of "full-blown" invasive cancer spans almost 12 years, future CTC studies should focus on screening and early detection of PDAC. CTCs have been detected in the early stages of PDAC, suggesting that metastasis may be an early event in PDAC. The early detection of PDAC could significantly improve the poor survival outcomes of PDAC when patients would be eligible for surgery and treatments are generally more effective. Screening using CTCs could be tested initially in "high risk individuals" before potentially extending this to the general population.

Reliable and consistent CTC detection remains a challenge as current reports have adapted different CTC isolation techniques. Consequently, downstream phenotypic analysis may be biased and thereby hinder the identification of the subpopulation/s responsible for PDAC metastasis. Advances in single-cell technologies will allow for comprehensive characterization of CTCs, leading to insights into CTC biology, PDAC metastasis, and tumor heterogeneity. Although further investigation is required to optimize culture conditions, CTC-derived organoids could facilitate personalized medicine approaches. Ultimately, CTCs may provide a unique role in resolving important biological questions in PDAC evolution and clinical management.

Author Contributions: All authors (D.Y., A.B., H.S., P.S., P.G. and J.E.J.R.) were involved in the conceptualization, writing of the original draft, and reviewing and editing the manuscript. D.Y. was also involved in the supervision and visualization. All authors have read and agreed to the published version of the manuscript.

Funding: Li Ka Shing Cell \& Gene Therapy Initiative to J.E.J.R.; Cancer Council NSW Project Grant RG20-07 to J.E.J.R.; Cancer Council NSW Pathways Grant PW18-03 to J.E.J.R.; National Health \& Medical Research Council Investigator Grant 1177305 to J.E.J.R.; CSR Australia project funding to J.E.J.R. \& D.Y.

Institutional Review Board Statement: Not applicable.

Informed Consent Statement: Not applicable.

Data Availability Statement: Data sharing is not applicable to this article. No new data were created or analyzed in this study.

Acknowledgments: Figures was created with BioRender.com (20 December 2021).

Conflicts of Interest: D.Y., A.B., H.S., P.S. and P.G. declare that they have no conflicts of interests. J.E.J.R. reports advisory roles in Gene Technology Technical Advisory Committee, Office of the Gene Technology Regulator, Australian Government. J.E.J.R. also reports honoraria speaker fees or advisory roles for GSK, Takeda, Gilead, Cynata, Pfizer, Spark, Novartis, Celgene, bluebird bio, Shire, Avrobio, ATARA, Bayer; stocks in Genea; consultant role for Rarecyte (stocks in lieu).

\section{References}

1. Henley, S.J.; Ward, E.M.; Scott, S.; Ma, J.; Anderson, R.N.; Firth, A.U.; Thomas, C.C.; Islami, F.; Weir, H.K.; Lewis, D.R.; et al. Annual Report to the Nation on the Status of Cancer, part I: National cancer statistics. Cancer 2020, 126, 2225-2249. [CrossRef]

2. Siegel, R.L.; Miller, K.D.; Fuchs, H.E.; Jemal, A. Cancer Statistics, 2021. CA Cancer J. Clin. 2021, 71, 7-33. [CrossRef] 
3. Rahib, L.; Smith, B.D.; Aizenberg, R.; Rosenzweig, A.B.; Fleshman, J.M.; Matrisian, L.M. Projecting cancer incidence and deaths to 2030: The unexpected burden of thyroid, liver, and pancreas cancers in the United States. Cancer Res. 2014, 74, $2913-2921$. [CrossRef]

4. Masiak-Segit, W.; Rawicz-Pruszynski, K.; Skorzewska, M.; Polkowski, W.P. Surgical treatment of pancreatic cancer. Pol. Przegl. Chir. 2018, 90, 45-53. [CrossRef]

5. Groot, V.P.; Gemenetzis, G.; Blair, A.B.; Rivero-Soto, R.J.; Yu, J.; Javed, A.A.; Burkhart, R.A.; Rinkes, I.; Molenaar, I.Q.; Cameron, J.L.; et al. Defining and Predicting Early Recurrence in 957 Patients With Resected Pancreatic Ductal Adenocarcinoma. Ann. Surg. 2019, 269, 1154-1162. [CrossRef]

6. Loveday, B.; Lipton, L.; Thomson, B. Pancreatic cancer. Aust. J. Gen. Pract. 2019, 48, 826-831. [CrossRef]

7. Christenson, E.S.; Jaffee, E.; Azad, N.S. Current and emerging therapies for patients with advanced pancreatic ductal adenocarcinoma: A bright future. Lancet Oncol. 2020, 21, e135-e145. [CrossRef]

8. Conroy, T.; Desseigne, F.; Ychou, M.; Bouche, O.; Guimbaud, R.; Becouarn, Y.; Adenis, A.; Raoul, J.L.; Gourgou-Bourgade, S.; de la Fouchardiere, C.; et al. FOLFIRINOX versus gemcitabine for metastatic pancreatic cancer. N. Engl. J. Med. 2011, 364, 1817-1825. [CrossRef]

9. Von Hoff, D.D.; Ervin, T.; Arena, F.P.; Chiorean, E.G.; Infante, J.; Moore, M.; Seay, T.; Tjulandin, S.A.; Ma, W.W.; Saleh, M.N.; et al Increased survival in pancreatic cancer with nab-paclitaxel plus gemcitabine. N. Engl. J. Med. 2013, 369, 1691-1703. [CrossRef]

10. Ballehaninna, U.K.; Chamberlain, R.S. The clinical utility of serum CA 19-9 in the diagnosis, prognosis and management of pancreatic adenocarcinoma: An evidence based appraisal. J. Gastrointest. Oncol. 2012, 3, 105-119. [CrossRef]

11. Hewitt, M.J.; McPhail, M.J.W.; Possamai, L.; Dhar, A.; Vlavianos, P.; Monahan, K.J. EUS-guided FNA for diagnosis of solid pancreatic neoplasms: A meta-analysis. Gastrointest. Endosc. 2012, 75, 319-331. [CrossRef]

12. Kitano, M.; Yoshida, T.; Itonaga, M.; Tamura, T.; Hatamaru, K.; Yamashita, Y. Impact of endoscopic ultrasonography on diagnosis of pancreatic cancer. J. Gastroenterol. 2019, 54, 19-32. [CrossRef]

13. Wang, K.-X.; Ben, Q.-W.; Jin, Z.-D.; Du, Y.-Q.; Zou, D.-W.; Liao, Z.; Li, Z.-S. Assessment of morbidity and mortality associated with EUS-guided FNA: A systematic review. Gastrointest. Endosc. 2011, 73, 283-290. [CrossRef]

14. Zhu, H.; Jiang, F.; Zhu, J.; Du, Y.; Jin, Z.; Li, Z. Assessment of morbidity and mortality associated with endoscopic ultrasoundguided fine-needle aspiration for pancreatic cystic lesions: A systematic review and meta-analysis. Dig. Endosc. 2017, 29, 667-675. [CrossRef]

15. Koay, E.J.; Amer, A.M.; Baio, F.E.; Ondari, A.O.; Fleming, J.B. Toward stratification of patients with pancreatic cancer: Past lessons from traditional approaches and future applications with physical biomarkers. Cancer Lett. 2016, 381, 237-243. [CrossRef]

16. Gerlinger, M.; Rowan, A.J.; Horswell, S.; Larkin, J.; Endesfelder, D.; Gronroos, E.; Martinez, P.; Matthews, N.; Stewart, A.; Tarpey, P.; et al. Intratumor Heterogeneity and Branched Evolution Revealed by Multiregion Sequencing. N. Engl. J. Med. 2012, 366, 883-892. [CrossRef]

17. Palmirotta, R.; Lovero, D.; Cafforio, P.; Felici, C.; Mannavola, F.; Pellè, E.; Quaresmini, D.; Tucci, M.; Silvestris, F. Liquid biopsy of cancer: A multimodal diagnostic tool in clinical oncology. Ther. Adv. Med. Oncol. 2018, 10, 1-24. [CrossRef]

18. Ferrone, C.R.; Finkelstein, D.M.; Thayer, S.P.; Muzikansky, A.; Castillo, C.F.-d.; Warshaw, A.L. Perioperative CA19-9 Levels Can Predict Stage and Survival in Patients With Resectable Pancreatic Adenocarcinoma. J. Clin. Oncol. 2006, 24, 2897-2902. [CrossRef]

19. Meng, Q.; Shi, S.; Liang, C.; Liang, D.; Xu, W.; Ji, S.; Zhang, B.; Ni, Q.; Xu, J.; Yu, X. Diagnostic and prognostic value of carcinoembryonic antigen in pancreatic cancer: A systematic review and meta-analysis. Oncotargets Ther. 2017, 10, 4591-4598. [CrossRef]

20. Duffy, M.J.; Sturgeon, C.; Lamerz, R.; Haglund, C.; Holubec, V.L.; Klapdor, R.; Nicolini, A.; Topolcan, O.; Heinemann, V. Tumor markers in pancreatic cancer: A European Group on Tumor Markers (EGTM) status report. Ann. Oncol. 2009, $21,441-447$. [CrossRef]

21. Patel, H.; Okamura, R.; Fanta, P.; Patel, C.; Lanman, R.B.; Raymond, V.M.; Kato, S.; Kurzrock, R. Clinical correlates of blood-derived circulating tumor DNA in pancreatic cancer. J. Hematol. Oncol. 2019, 12, 130. [CrossRef]

22. Guo, S.; Shi, X.; Shen, J.; Gao, S.; Wang, H.; Shen, S.; Pan, Y.; Li, B.; Xu, X.; Shao, Z.; et al. Preoperative detection of KRAS G12D mutation in ctDNA is a powerful predictor for early recurrence of resectable PDAC patients. Br. J. Cancer 2020, 122, 857-867. [CrossRef]

23. Buscail, E.; Alix-Panabières, C.; Quincy, P.; Cauvin, T.; Chauvet, A.; Degrandi, O.; Caumont, C.; Verdon, S.; Lamrissi, I.; Moranvillier, I.; et al. High clinical value of liquid biopsy to detect circulating tumor cells and tumor exosomes in pancreatic ductal adenocarcinoma patients eligible for up-front surgery. Cancers 2019, 11, 1656. [CrossRef]

24. Mehta, K.Y.; Wu, H.-J.; Menon, S.S.; Fallah, Y.; Zhong, X.; Rizk, N.; Unger, K.; Mapstone, M.; Fiandaca, M.S.; Federoff, H.J.; et al. Metabolomic biomarkers of pancreatic cancer: A meta-analysis study. Oncotarget 2017, 8, 68899-68915. [CrossRef]

25. Sharma, G.G.; Okada, Y.; Von Hoff, D.; Goel, A. Non-coding RNA biomarkers in pancreatic ductal adenocarcinoma. Semin. Cancer Biol. 2020, 75, 153-168. [CrossRef]

26. Habib, J.R.; Yu, J. Circulating tumor cells in pancreatic cancer. J. Pancreatol. 2019, 2, 54-59. [CrossRef]

27. Martini, V.; Timme-Bronsert, S.; Fichtner-Feigl, S.; Hoeppner, J.; Kulemann, B. Circulating Tumor Cells in Pancreatic Cancer: Current Perspectives. Cancers 2019, 11, 1659. [CrossRef]

28. Fleischhacker, M.; Schmidt, B. Circulating nucleic acids (CNAs) and cancer-A survey. Biochim. Et Biophys. Acta Rev. Cancer 2007, 1775, 181-232. [CrossRef] 
29. Meddeb, R.; Dache, Z.A.A.; Thezenas, S.; Otandault, A.; Tanos, R.; Pastor, B.; Sanchez, C.; Azzi, J.; Tousch, G.; Azan, S.; et al. Quantifying circulating cell-free DNA in humans. Sci. Rep. 2019, 9, 5220. [CrossRef]

30. Sivapalan, L.; Kocher, H.M.; Ross-Adams, H.; Chelala, C. Molecular profiling of ctDNA in pancreatic cancer: Opportunities and challenges for clinical application. Pancreatology 2021, 21, 363-378. [CrossRef]

31. Buscail, E.; Maulat, C.; Muscari, F.; Chiche, L.; Cordelier, P.; Dabernat, S.; Alix-Panabières, C.; Buscail, L. Liquid Biopsy Approach for Pancreatic Ductal Adenocarcinoma. Cancers 2019, 11, 852. [CrossRef]

32. Lee, J.S.; Rhee, T.M.; Pietrasz, D.; Bachet, J.B.; Laurent-Puig, P.; Kong, S.Y.; Takai, E.; Yachida, S.; Shibata, T.; Lee, J.W.; et al Circulating tumor DNA as a prognostic indicator in resectable pancreatic ductal adenocarcinoma: A systematic review and meta-analysis. Sci. Rep. 2019, 9, 16971. [CrossRef]

33. Lee, B.; Lipton, L.; Cohen, J.; Tie, J.; Javed, A.A.; Li, L.; Goldstein, D.; Burge, M.; Cooray, P.; Nagrial, A.; et al. Circulating tumor DNA as a potential marker of adjuvant chemotherapy benefit following surgery for localized pancreatic cancer. Ann. Oncol. 2019, 30, 1472-1478. [CrossRef]

34. Jiang, J.; Ye, S.; Xu, Y.; Chang, L.; Hu, X.; Ru, G.; Guo, Y.; Yi, X.; Yang, L.; Huang, D. Circulating Tumor DNA as a Potential Marker to Detect Minimal Residual Disease and Predict Recurrence in Pancreatic Cancer. Front. Oncol. 2020, 10, 1220. [CrossRef]

35. Caby, M.P.; Lankar, D.; Vincendeau-Scherrer, C.; Raposo, G.; Bonnerot, C. Exosomal-like vesicles are present in human blood plasma. Int. Immunol. 2005, 17, 879-887. [CrossRef]

36. Chen, K.; Wang, Q.; Kornmann, M.; Tian, X.; Yang, Y. The Role of Exosomes in Pancreatic Cancer From Bench to Clinical Application: An Updated Review. Front. Oncol. 2021, 11, 644358. [CrossRef]

37. Huang, T.; Deng, C.X. Current Progresses of Exosomes as Cancer Diagnostic and Prognostic Biomarkers. Int. J. Biol. Sci. 2019, 15, 1-11. [CrossRef]

38. Kamerkar, S.; LeBleu, V.S.; Sugimoto, H.; Yang, S.; Ruivo, C.F.; Melo, S.A.; Lee, J.J.; Kalluri, R. Exosomes facilitate therapeutic targeting of oncogenic KRAS in pancreatic cancer. Nature 2017, 546, 498-503. [CrossRef]

39. Chang, C.H.; Pauklin, S. Extracellular vesicles in pancreatic cancer progression and therapies. Cell Death Dis. 2021, $12,973$. [CrossRef]

40. Kulemann, B.; Pitman, M.B.; Liss, A.S.; Valsangkar, N.; Fernández-Del Castillo, C.; Lillemoe, K.D.; Hoeppner, J.; Mino-Kenudson, M.; Warshaw, A.L.; Thayer, S.P. Circulating tumor cells found in patients with localized and advanced pancreatic cancer. Pancreas 2015, 44, 547-550. [CrossRef]

41. Amantini, C.; Morelli, M.B.; Nabissi, M.; Piva, F.; Marinelli, O.; Maggi, F.; Bianchi, F.; Bittoni, A.; Berardi, R.; Giampieri, R.; et al. Expression Profiling of Circulating Tumor Cells in Pancreatic Ductal Adenocarcinoma Patients: Biomarkers Predicting Overall Survival. Front. Oncol. 2019, 9, 874. [CrossRef]

42. Yu, K.H.; Ricigliano, M.; Hidalgo, M.; Abou-Alfa, G.K.; Lowery, M.A.; Saltz, L.B.; Crotty, J.F.; Gary, K.; Cooper, B.; Lapidus, R.; et al. Pharmacogenomic modeling of circulating tumor and invasive cells for prediction of chemotherapy response and resistance in pancreatic cancer. Clin. Cancer Res. 2014, 20, 5281-5289. [CrossRef]

43. Khoo, B.L.; Grenci, G.; Lim, Y.B.; Lee, S.C.; Han, J.; Lim, C.T. Expansion of patient-derived circulating tumor cells from liquid biopsies using a CTC microfluidic culture device. Nat. Protoc. 2018, 13, 34-58. [CrossRef]

44. Pishvaian, M.J.; Bender, R.J.; Halverson, D.; Rahib, L.; Hendifar, A.E.; Mikhail, S.; Chung, V.; Picozzi, V.J.; Sohal, D.; Blais, E.M.; et al. Molecular profiling of patients with pancreatic cancer: Initial results from the know your tumor initiative. Clin. Cancer Res. 2018, 24, 5018-5027. [CrossRef]

45. Pishvaian, M.J.; Blais, E.M.; Brody, J.R.; Lyons, E.; DeArbeloa, P.; Hendifar, A.; Mikhail, S.; Chung, V.; Sahai, V.; Sohal, D.P.S.; et al. Overall survival in patients with pancreatic cancer receiving matched therapies following molecular profiling: A retrospective analysis of the Know Your Tumor registry trial. Lancet Oncol. 2020, 21, 508-518. [CrossRef]

46. Massagué, J.; Obenauf, A.C. Metastatic colonization by circulating tumour cells. Nature 2016, 529, 298-306. [CrossRef]

47. Bidard, F.C.; Peeters, D.J.; Fehm, T.; Nolé, F.; Gisbert-Criado, R.; Mavroudis, D.; Grisanti, S.; Generali, D.; Garcia-Saenz, J.A.; Stebbing, J.; et al. Clinical validity of circulating tumour cells in patients with metastatic breast cancer: A pooled analysis of individual patient data. Lancet Oncol. 2014, 15, 406-414. [CrossRef]

48. Lim, S.H.; Becker, T.M.; Chua, W.; Caixeiro, N.J.; Ng, W.L.; Kienzle, N.; Tognela, A.; Lumba, S.; Rasko, J.E.; de Souza, P.; et al. Circulating tumour cells and circulating free nucleic acid as prognostic and predictive biomarkers in colorectal cancer. Cancer Lett. 2014, 346, 24-33. [CrossRef]

49. Antonarakis, E.S.; Lu, C.; Luber, B.; Wang, H.; Chen, Y.; Zhu, Y.; Silberstein, J.L.; Taylor, M.N.; Maughan, B.L.; Denmeade, S.R.; et al. Clinical significance of androgen receptor splice variant-7 mRNA detection in circulating tumor cells of men with metastatic castration-resistant prostate cancer treated with first \& second-line Abiraterone \& Enzalutamide. J. Clin. Oncol. 2017, 35, 2149-2156. [CrossRef]

50. DiPardo, B.J.; Winograd, P.; Court, C.M.; Tomlinson, J.S. Pancreatic cancer circulating tumor cells: Applications for personalized oncology. Expert Rev. Mol. Diagn. 2018, 18, 809-820. [CrossRef]

51. Ashworth, T.R. A case of cancer in which cells similar to those in the tumours were seen in the blood after death. Aust. Med. J. $1869,14,146-147$.

52. Allard, W.J.; Matera, J.; Miller, M.C.; Repollet, M.; Connelly, M.C.; Rao, C.; Tibbe, A.G.; Uhr, J.W.; Terstappen, L.W. Tumor cells circulate in the peripheral blood of all major carcinomas but not in healthy subjects or patients with nonmalignant diseases. Clin. Cancer Res. 2004, 10, 6897-6904. [CrossRef] 
53. Poudineh, M.; Sargent, E.H.; Pantel, K.; Kelley, S.O. Profiling circulating tumour cells and other biomarkers of invasive cancers. Nat. Biomed. Eng. 2018, 2, 72-84. [CrossRef]

54. Mataki, Y. Carcinoembryonic Antigen Messenger RNA Expression Using Nested Reverse Transcription-PCR in the Peripheral Blood During Follow-up Period of Patients Who Underwent Curative Surgery for Biliary-Pancreatic Cancer: Longitudinal Analyses. Clin. Cancer Res. 2004, 10, 3807-3814. [CrossRef]

55. Soeth, E.; Grigoleit, U.; Moellmann, B.; Röder, C.; Schniewind, B.; Kremer, B.; Kalthoff, H.; Vogel, I. Detection of tumor cell dissemination in pancreatic ductal carcinoma patients by CK 20 RT-PCR indicates poor survival. J. Cancer Res. Clin. Oncol. 2005, 131, 669-676. [CrossRef]

56. Hoffmann, K.; Kerner, C.; Wilfert, W.; Mueller, M.; Thiery, J.; Hauss, J.; Witzigmann, H. Detection of disseminated pancreatic cells by amplification of cytokeratin-19 with quantitative RT-PCR in blood, bone marrow and peritoneal lavage of pancreatic carcinoma patients. World J. Gastroenterol. 2007, 13, 257-263. [CrossRef]

57. Khoja, L.; Backen, A.; Sloane, R.; Menasce, L.; Ryder, D.; Krebs, M.; Board, R.; Clack, G.; Hughes, A.; Blackhall, F.; et al. A pilot study to explore circulating tumour cells in pancreatic cancer as a novel biomarker. Br. J. Cancer 2012, 106, 508-516. [CrossRef]

58. Poruk, K.E.; Valero, V., 3rd; Saunders, T.; Blackford, A.L.; Griffin, J.F.; Poling, J.; Hruban, R.H.; Anders, R.A.; Herman, J.; Zheng, L.; et al. Circulating Tumor Cell Phenotype Predicts Recurrence and Survival in Pancreatic Adenocarcinoma. Ann. Surg. 2016, 264, 1073-1081. [CrossRef]

59. Poruk, K.E.; Blackford, A.L.; Weiss, M.J.; Cameron, J.L.; He, J.; Goggins, M.; Rasheed, Z.A.; Wolfgang, C.L.; Wood, L.D. Circulating tumor cells expressing markers of tumor-initiating cells predict poor survival and cancer recurrence in patients with pancreatic ductal adenocarcinoma. Clin. Cancer Res. 2017, 23, 2681-2690. [CrossRef]

60. Bobek, V.; Gurlich, R.; Eliasova, P.; Kolostova, K. Circulating tumor cells in pancreatic cancer patients: Enrichment and cultivation. World J. Gastroenterol. 2014, 20, 17163-17170. [CrossRef]

61. Sefrioui, D.; Blanchard, F.; Toure, E.; Basile, P.; Beaussire, L.; Dolfus, C.; Perdrix, A.; Paresy, M.; Antonietti, M.; Iwanicki-Caron, I.; et al. Diagnostic value of CA19.9, circulating tumour DNA and circulating tumour cells in patients with solid pancreatic tumours. Br. J. Cancer 2017, 117, 1017-1025. [CrossRef] [PubMed]

62. Ankeny, J.S.; Court, C.M.; Hou, S.; Li, Q.; Song, M.; Wu, D.; Chen, J.F.; Lee, T.; Lin, M.; Sho, S.; et al. Circulating tumour cells as a biomarker for diagnosis and staging in pancreatic cancer. Br. J. Cancer 2016, 114, 1367-1375. [CrossRef] [PubMed]

63. Court, C.M.; Ankeny, J.S.; Sho, S.; Winograd, P.; Hou, S.; Song, M.; Wainberg, Z.A.; Girgis, M.D.; Graeber, T.G.; Agopian, V.G.; et al. Circulating Tumor Cells Predict Occult Metastatic Disease and Prognosis in Pancreatic Cancer. Ann. Surg. Oncol. 2018, 25, 1000-1008. [CrossRef] [PubMed]

64. Sun, Y.; Wu, G.; Cheng, K.S.; Chen, A.; Neoh, K.H.; Chen, S.; Tang, Z.; Lee, P.F.; Dai, M.; Han, R.P.S. CTC phenotyping for a preoperative assessment of tumor metastasis and overall survival of pancreatic ductal adenocarcinoma patients. EBioMedicine 2019, 46, 133-149. [CrossRef] [PubMed]

65. Varillas, J.I.; Zhang, J.; Chen, K.; Barnes, I.I.; Liu, C.; George, T.J.; Fan, Z.H. Microfluidic isolation of circulating tumor cells and cancer stem-like cells from patients with pancreatic ductal adenocarcinoma. Theranostics 2019, 9, 1417-1425. [CrossRef] [PubMed]

66. Pahattuge, T.N.; Freed, I.M.; Hupert, M.L.; Vaidyanathan, S.; Childers, K.; Witek, M.A.; Weerakoon-Ratnayake, K.; Park, D.; Kasi, A.; Al-Kasspooles, M.F.; et al. System Modularity Chip for Analysis of Rare Targets (SMART-Chip): Liquid Biopsy Samples. ACS Sens. 2021, 6, 1831-1839. [CrossRef] [PubMed]

67. Dong, Y.; Skelley, A.M.; Merdek, K.D.; Sprott, K.M.; Jiang, C.; Pierceall, W.E.; Lin, J.; Stocum, M.; Carney, W.P.; Smirnov, D.A. Microfluidics and circulating tumor cells. J. Mol. Diagn. 2013, 15, 149-157. [CrossRef]

68. Zou, D.; Cui, D. Advances in isolation and detection of circulating tumor cells based on microfluidics. Cancer Biol. Med. 2018, 15, 335-353. [CrossRef]

69. Okubo, K.; Uenosono, Y.; Arigami, T.; Mataki, Y.; Matsushita, D.; Yanagita, S.; Kurahara, H.; Sakoda, M.; Kijima, Y.; Maemura, K.; et al. Clinical impact of circulating tumor cells and therapy response in pancreatic cancer. Eur. J. Surg. Oncol. 2017, 43, 1050-1055. [CrossRef]

70. Effenberger, K.E.; Schroeder, C.; Hanssen, A.; Wolter, S.; Eulenburg, C.; Tachezy, M.; Gebauer, F.; Izbicki, J.R.; Pantel, K.; Bockhorn, M. Improved Risk Stratification by Circulating Tumor Cell Counts in Pancreatic Cancer. Clin. Cancer Res. 2018, 24, 2844-2850. [CrossRef]

71. Hugenschmidt, H.; Labori, K.J.; Borgen, E.; Brunborg, C.; Schirmer, C.B.; Seeberg, L.T.; Naume, B.; Wiedswang, G. Preoperative ctc-detection by cellsearch ${ }^{\circledR}$ is associated with early distant metastasis and impaired survival in resected pancreatic cancer. Cancers 2021, 13, 485. [CrossRef] [PubMed]

72. Habli, Z.; AlChamaa, W.; Saab, R.; Kadara, H.; Khraiche, M.L. Circulating Tumor Cell Detection Technologies and Clinical Utility: Challenges and Opportunities. Cancers 2020, 12, 1930. [CrossRef] [PubMed]

73. Ren, C.; Han, C.; Zhang, J.; He, P.; Wang, D.; Wang, B.; Zhao, P.; Zhao, X. Detection of apoptotic circulating tumor cells in advanced pancreatic cancer following 5-fluorouracil chemotherapy. Cancer Biol. Ther. 2011, 12, 700-706. [CrossRef] [PubMed]

74. Kaldjian, E.P.; Ramirez, A.B.; Sun, Y.; Campton, D.E.; Werbin, J.L.; Varshavskaya, P.; Quarre, S.; George, T.; Madan, A.; Blau, C.A.; et al. The RareCyte(R) platform for next-generation analysis of circulating tumor cells. Cytom. A 2018, 93, 1220-1225. [CrossRef]

75. Werner, S.L.; Graf, R.P.; Landers, M.; Valenta, D.T.; Schroeder, M.; Greene, S.B.; Bales, N.; Dittamore, R.; Marrinucci, D. Analytical Validation and Capabilities of the Epic CTC Platform: Enrichment-Free Circulating Tumour Cell Detection and Characterization. J. Circ. Biomark 2015, 4, 3. [CrossRef] 
76. Kurihara, T.; Itoi, T.; Sofuni, A.; Itokawa, F.; Tsuchiya, T.; Tsuji, S.; Ishii, K.; Ikeuchi, N.; Tsuchida, A.; Kasuya, K.; et al. Detection of circulating tumor cells in patients with pancreatic cancer: A preliminary result. J. Hepatobiliary Pancreat. Surg. 2008, 15, 189-195. [CrossRef]

77. Bidard, F.C.; Huguet, F.; Louvet, C.; Mineur, L.; Bouche, O.; Chibaudel, B.; Artru, P.; Desseigne, F.; Bachet, J.B.; Mathiot, C.; et al. Circulating tumor cells in locally advanced pancreatic adenocarcinoma: The ancillary CirCe 07 study to the LAP 07 trial. Ann. Oncol. 2013, 24, 2057-2061. [CrossRef]

78. Bissolati, M.; Sandri, M.T.; Burtulo, G.; Zorzino, L.; Balzano, G.; Braga, M. Portal vein-circulating tumor cells predict liver metastases in patients with resectable pancreatic cancer. Tumour Biol. 2015, 36, 991-996. [CrossRef]

79. Earl, J.; Garcia-Nieto, S.; Martinez-Avila, J.C.; Montans, J.; Sanjuanbenito, A.; Rodriguez-Garrote, M.; Lisa, E.; Mendia, E.; Lobo, E.; Malats, N.; et al. Circulating tumor cells (Ctc) and kras mutant circulating free Dna (cfdna) detection in peripheral blood as biomarkers in patients diagnosed with exocrine pancreatic cancer. BMC Cancer 2015, 15, 797. [CrossRef]

80. Catenacci, D.V.; Chapman, C.G.; Xu, P.; Koons, A.; Konda, V.J.; Siddiqui, U.D.; Waxman, I. Acquisition of Portal Venous Circulating Tumor Cells From Patients With Pancreaticobiliary Cancers by Endoscopic Ultrasound. Gastroenterology 2015, 149, 1794-1803.e1794. [CrossRef]

81. Dotan, E.; Alpaugh, R.K.; Ruth, K.; Negin, B.P.; Denlinger, C.S.; Hall, M.J.; Astsaturov, I.; McAleer, C.; Fittipaldi, P.; ThrashBingham, C.; et al. Prognostic Significance of MUC-1 in Circulating Tumor Cells in Patients With Metastatic Pancreatic Adenocarcinoma. Pancreas 2016, 45, 1131-1135. [CrossRef] [PubMed]

82. White, M.G.; Lee, A.; Vicente, D.; Hall, C.; Kim, M.P.; Katz, M.H.G.; Lee, J.E.; Ikoma, N.; Lucci, A.; Tzeng, C.D. Measurement of Portal Vein Blood Circulating Tumor Cells is Safe and May Correlate With Outcomes in Resected Pancreatic Ductal Adenocarcinoma. Ann. Surg. Oncol. 2021, 28, 4615-4622. [CrossRef]

83. Rodriguez-Lee, M.; Kolatkar, A.; McCormick, M.; Dago, A.D.; Kendall, J.; Carlsson, N.A.; Bethel, K.; Greenspan, E.J.; Hwang, S.E.; Waitman, K.R.; et al. Effect of Blood Collection Tube Type and Time to Processing on the Enumeration and High-Content Characterization of Circulating Tumor Cells Using the High-Definition Single-Cell Assay. Arch. Pathol. Lab. Med. 2018, 142, 198-207. [CrossRef] [PubMed]

84. Salvianti, F.; Gelmini, S.; Costanza, F.; Mancini, I.; Sonnati, G.; Simi, L.; Pazzagli, M.; Pinzani, P. The pre-analytical phase of the liquid biopsy. New Biotechnol. 2020, 55, 19-29. [CrossRef] [PubMed]

85. Chari, S.T. Detecting early pancreatic cancer: Problems and prospects. Semin. Oncol. 2007, 34, 284-294. [CrossRef]

86. Kromrey, M.L.; Bulow, R.; Hubner, J.; Paperlein, C.; Lerch, M.M.; Ittermann, T.; Volzke, H.; Mayerle, J.; Kuhn, J.P. Prospective study on the incidence, prevalence and 5-year pancreatic-related mortality of pancreatic cysts in a population-based study. Gut 2018, 67, 138-145. [CrossRef] [PubMed]

87. Bhosale, P.; Balachandran, A.; Tamm, E. Imaging of benign and malignant cystic pancreatic lesions and a strategy for follow up World J. Radiol. 2010, 2, 345-353. [CrossRef] [PubMed]

88. Bhutani, M.S.; Koduru, P.; Joshi, V.; Saxena, P.; Suzuki, R.; Irisawa, A.; Yamao, K. The role of endoscopic ultrasound in pancreatic cancer screening. Endosc. Ultrasound 2016, 5, 8-16. [CrossRef]

89. Konings, I.; Canto, M.I.; Almario, J.A.; Harinck, F.; Saxena, P.; Lucas, A.L.; Kastrinos, F.; Whitcomb, D.C.; Brand, R.E.; Lachter, J.; et al. Surveillance for pancreatic cancer in high-risk individuals. BJS Open 2019, 3, 656-665. [CrossRef]

90. Rhim, A.D.; Mirek, E.T.; Aiello, N.M.; Maitra, A.; Bailey, J.M.; McAllister, F.; Reichert, M.; Beatty, G.L.; Rustgi, A.K.; Vonderheide, R.H.; et al. EMT and dissemination precede pancreatic tumor formation. Cell 2012, 148, 349-361. [CrossRef]

91. Rhim, A.D.; Thege, F.I.; Santana, S.M.; Lannin, T.B.; Saha, T.N.; Tsai, S.; Maggs, L.R.; Kochman, M.L.; Ginsberg, G.G.; Lieb, J.G.; et al. Detection of circulating pancreas epithelial cells in patients with pancreatic cystic lesions. Gastroenterology 2014, 146, 647-651. [CrossRef] [PubMed]

92. Cauley, C.E.; Pitman, M.B.; Zhou, J.; Perkins, J.; Kuleman, B.; Liss, A.S.; Fernandez-Del Castillo, C.; Warshaw, A.L.; Lillemoe, K.D.; Thayer, S.P. Circulating Epithelial Cells in Patients with Pancreatic Lesions: Clinical and Pathologic Findings. J. Am. Coll. Surg. 2015, 221, 699-707. [CrossRef] [PubMed]

93. Poruk, K.E.; Valero, V., 3rd; He, J.; Ahuja, N.; Cameron, J.L.; Weiss, M.J.; Lennon, A.M.; Goggins, M.; Wood, L.D.; Wolfgang, C.L. Circulating Epithelial Cells in Intraductal Papillary Mucinous Neoplasms and Cystic Pancreatic Lesions. Pancreas 2017, 46, 943-947. [CrossRef] [PubMed]

94. Franses, J.W.; Basar, O.; Kadayifci, A.; Yuksel, O.; Choz, M.; Kulkarni, A.S.; Tai, E.; Vo, K.D.; Arora, K.S.; Desai, N.; et al. Improved Detection of Circulating Epithelial Cells in Patients with Intraductal Papillary Mucinous Neoplasms. Oncologist 2018, 23, 121-127. [CrossRef] [PubMed]

95. Mishra, A.; Dubash, T.D.; Edd, J.F.; Jewett, M.K.; Garre, S.G.; Karabacak, N.M.; Rabe, D.C.; Mutlu, B.R.; Walsh, J.R.; Kapur, R.; et al. Ultrahigh-throughput magnetic sorting of large blood volumes for epitope-agnostic isolation of circulating tumor cells. Proc. Natl. Acad. Sci. USA 2020, 117, 16839-16847. [CrossRef]

96. Rosenbaum, M.W.; Cauley, C.E.; Kulemann, B.; Liss, A.S.; Castillo, C.F.; Warshaw, A.L.; Lillemoe, K.D.; Thayer, S.P.; Pitman, M.B. Cytologic characteristics of circulating epithelioid cells in pancreatic disease. Cancer Cytopathol. 2017, 125, 332-340. [CrossRef]

97. Wei, T.; Zhang, X.; Zhang, Q.; Yang, J.; Chen, Q.; Wang, J.; Li, X.; Chen, J.; Ma, T.; Li, G.; et al. Vimentin-positive circulating tumor cells as a biomarker for diagnosis and treatment monitoring in patients with pancreatic cancer. Cancer Lett. 2019, 452, 237-243. [CrossRef] 
98. Chen, X.; Gole, J.; Gore, A.; He, Q.; Lu, M.; Min, J.; Yuan, Z.; Yang, X.; Jiang, Y.; Zhang, T.; et al. Non-invasive early detection of cancer four years before conventional diagnosis using a blood test. Nat. Commun. 2020, 11, 3475. [CrossRef]

99. Yachida, S.; Jones, S.; Bozic, I.; Antal, T.; Leary, R.; Fu, B.; Kamiyama, M.; Hruban, R.H.; Eshleman, J.R.; Nowak, M.A.; et al. Distant metastasis occurs late during the genetic evolution of pancreatic cancer. Nature 2010, 467, 1114-1117. [CrossRef]

100. Tan, Y.; $\mathrm{Wu}, \mathrm{H}$. The significant prognostic value of circulating tumor cells in colorectal cancer: A systematic review and meta-analysis. Curr. Probl. Cancer 2018, 42, 95-106. [CrossRef]

101. Lu, Y.J.; Wang, P.; Peng, J.; Wang, X.; Zhu, Y.W.; Shen, N. Meta-analysis Reveals the Prognostic Value of Circulating Tumour Cells Detected in the Peripheral Blood in Patients with Non-Metastatic Colorectal Cancer. Sci. Rep. 2017, 7, 905. [CrossRef] [PubMed]

102. Jiang, H.; Gu, X.; Zuo, Z.; Tian, G.; Liu, J. Prognostic value of circulating tumor cells in patients with bladder cancer: A meta-analysis. PLOS ONE 2021, 16, e0254433. [CrossRef] [PubMed]

103. Wang, C.H.; Chang, C.J.; Yeh, K.Y.; Chang, P.H.; Huang, J.S. The Prognostic Value of HER2-Positive Circulating Tumor Cells in Breast Cancer Patients: A Systematic Review and Meta-Analysis. Clin. Breast Cancer 2017, 17, 341-349. [CrossRef] [PubMed]

104. Han, L.; Chen, W.; Zhao, Q. Prognostic value of circulating tumor cells in patients with pancreatic cancer: A meta-analysis. Tumour Biol. 2014, 35, 2473-2480. [CrossRef]

105. Pang, T.C.Y.; Po, J.W.; Becker, T.M.; Goldstein, D.; Pirola, R.C.; Wilson, J.S.; Apte, M.V. Circulating tumour cells in pancreatic cancer: A systematic review and meta-analysis of clinicopathological implications. Pancreatology 2021, 21, 103-114. [CrossRef]

106. Wang, Y.; Yu, X.; Hartmann, D.; Zhou, J. Circulating tumor cells in peripheral blood of pancreatic cancer patients and their prognostic role: A systematic review and meta-analysis. HPB 2020, 22, 660-669. [CrossRef]

107. Gemenetzis, G.; Groot, V.P.; Yu, J.; Ding, D.; Teinor, J.A.; Javed, A.A.; Wood, L.D.; Burkhart, R.A.; Cameron, J.L.; Makary, M.A.; et al. Circulating Tumor Cells Dynamics in Pancreatic Adenocarcinoma Correlate With Disease Status: Results of the Prospective CLUSTER Study. Ann. Surg. 2018, 268, 408-420. [CrossRef]

108. Zhu, P.; Liu, H.Y.; Liu, F.C.; Gu, F.M.; Yuan, S.X.; Huang, J.; Pan, Z.Y.; Wang, W.J. Circulating Tumor Cells Expressing Kruppel-Like Factor 8 and Vimentin as Predictors of Poor Prognosis in Pancreatic Cancer Patients. Cancer Control. 2021, $28,10732748211027163$. [CrossRef]

109. Song, B.G.; Kwon, W.; Kim, H.; Lee, E.M.; Han, Y.M.; Kim, H.; Byun, Y.; Lee, K.B.; Lee, K.H.; Lee, K.T.; et al. Detection of Circulating Tumor Cells in Resectable Pancreatic Ductal Adenocarcinoma: A Prospective Evaluation as a Prognostic Marker. Front. Oncol. 2020, 10, 616440. [CrossRef]

110. Park, Y.; Jun, H.R.; Choi, H.W.; Hwang, D.W.; Lee, J.H.; Song, K.B.; Lee, W.; Kwon, J.; Ha, S.H.; Jun, E.; et al. Circulating tumour cells as an indicator of early and systemic recurrence after surgical resection in pancreatic ductal adenocarcinoma. Sci. Rep. 2021, 11, 1644. [CrossRef]

111. Gardner, K.P.; Aldakkak, M.; Tang, C.M.; Tsai, S.; Adams, D.L. Circulating stromal cells in resectable pancreatic cancer correlates to pathological stage and predicts for poor clinical outcomes. NPJ Precis. Oncol. 2021, 5, 25. [CrossRef] [PubMed]

112. Michelakos, T.; Pergolini, I.; Castillo, C.F.; Honselmann, K.C.; Cai, L.; Deshpande, V.; Wo, J.Y.; Ryan, D.P.; Allen, J.N.; Blaszkowsky, L.S.; et al. Predictors of Resectability and Survival in Patients With Borderline and Locally Advanced Pancreatic Cancer who Underwent Neoadjuvant Treatment With FOLFIRINOX. Ann. Surg. 2019, 269, 733-740. [CrossRef] [PubMed]

113. Hamza, B.; Miller, A.B.; Meier, L.; Stockslager, M.; Ng, S.R.; King, E.M.; Lin, L.; DeGouveia, K.L.; Mulugeta, N.; Calistri, N.L.; et al. Measuring kinetics and metastatic propensity of CTCs by blood exchange between mice. Nat. Commun. 2021, 12, 5680. [CrossRef] [PubMed]

114. Fischer, K.R.; Durrans, A.; Lee, S.; Sheng, J.; Li, F.; Wong, S.T.; Choi, H.; El Rayes, T.; Ryu, S.; Troeger, J.; et al. Epithelialto-mesenchymal transition is not required for lung metastasis but contributes to chemoresistance. Nature 2015, 527, $472-476$. [CrossRef] [PubMed]

115. Guan, X.; Ma, F.; Li, C.; Wu, S.; Hu, S.; Huang, J.; Sun, X.; Wang, J.; Luo, Y.; Cai, R.; et al. The prognostic and therapeutic implications of circulating tumor cell phenotype detection based on epithelial-mesenchymal transition markers in the first-line chemotherapy of HER2-negative metastatic breast cancer. Cancer Commun. 2019, 39, 1. [CrossRef]

116. Papadaki, M.A.; Stoupis, G.; Theodoropoulos, P.A.; Mavroudis, D.; Georgoulias, V.; Agelaki, S. Circulating Tumor Cells with Stemness and Epithelial-to-Mesenchymal Transition Features Are Chemoresistant and Predictive of Poor Outcome in Metastatic Breast Cancer. Mol. Cancer 2019, 18, 437-447. [CrossRef]

117. Semaan, A.; Bernard, V.; Kim, D.U.; Lee, J.J.; Huang, J.; Kamyabi, N.; Stephens, B.M.; Qiao, W.; Varadhachary, G.R.; Katz, M.H.; et al. Characterisation of circulating tumour cell phenotypes identifies a partial-EMT sub-population for clinical stratification of pancreatic cancer. Br. J. Cancer 2021, 124, 1970-1977. [CrossRef]

118. Zhao, X.H.; Wang, Z.R.; Chen, C.L.; Di, L.; Bi, Z.F.; Li, Z.H.; Liu, Y.M. Molecular detection of epithelial-mesenchymal transition markers in circulating tumor cells from pancreatic cancer patients: Potential role in clinical practice. World J. Gastroenterol. 2019, 25, 138-150. [CrossRef]

119. Hermann, P.C.; Huber, S.L.; Herrler, T.; Aicher, A.; Ellwart, J.W.; Guba, M.; Bruns, C.J.; Heeschen, C. Distinct populations of cancer stem cells determine tumor growth and metastatic activity in human pancreatic cancer. Cell Stem Cell 2007, 1, 313-323. [CrossRef]

120. Jimeno, A.; Feldmann, G.; Suarez-Gauthier, A.; Rasheed, Z.; Solomon, A.; Zou, G.M.; Rubio-Viqueira, B.; Garcia-Garcia, E.; Lopez-Rios, F.; Matsui, W.; et al. A direct pancreatic cancer xenograft model as a platform for cancer stem cell therapeutic development. Mol. Cancer 2009, 8, 310-314. [CrossRef] 
121. Lytle, N.K.; Ferguson, L.P.; Rajbhandari, N.; Gilroy, K.; Fox, R.G.; Deshpande, A.; Schurch, C.M.; Hamilton, M.; Robertson, N.; Lin, W.; et al. A Multiscale Map of the Stem Cell State in Pancreatic Adenocarcinoma. Cell 2019, 177, 572-586.e22. [CrossRef] [PubMed]

122. Franses, J.W.; Philipp, J.; Missios, P.; Bhan, I.; Liu, A.; Yashaswini, C.; Tai, E.; Zhu, H.; Ligorio, M.; Nicholson, B.; et al. Pancreatic circulating tumor cell profiling identifies LIN28B as a metastasis driver and drug target. Nat. Commun. 2020, 11, 3303. [CrossRef] [PubMed]

123. Schuster, E.; Taftaf, R.; Reduzzi, C.; Albert, M.K.; Romero-Calvo, I.; Liu, H. Better together: Circulating tumor cell clustering in metastatic cancer. Trends Cancer 2021, 7, 1020-1032. [CrossRef] [PubMed]

124. Fabisiewicz, A.; Grzybowska, E. CTC clusters in cancer progression and metastasis. Med. Oncol. 2017, 34, 12. [CrossRef]

125. Lim, M.; Park, S.; Jeong, H.-O.; Park, S.H.; Kumar, S.; Jang, A.; Lee, S.; Kim, D.U.; Cho, Y.-K. Circulating Tumor Cell Clusters Are Cloaked with Platelets and Correlate with Poor Prognosis in Unresectable Pancreatic Cancer. Cancers 2021, 13, 5272. [CrossRef]

126. Szczerba, B.M.; Castro-Giner, F.; Vetter, M.; Krol, I.; Gkountela, S.; Landin, J.; Scheidmann, M.C.; Donato, C.; Scherrer, R.; Singer, J.; et al. Neutrophils escort circulating tumour cells to enable cell cycle progression. Nature 2019, 566, 553-557. [CrossRef]

127. Chang, M.C.; Chang, Y.T.; Chen, J.Y.; Jeng, Y.M.; Yang, C.Y.; Tien, Y.W.; Yang, S.H.; Chen, H.L.; Liang, T.Y.; Wang, C.F.; et al. Clinical Significance of Circulating Tumor Microemboli as a Prognostic Marker in Patients with Pancreatic Ductal Adenocarcinoma. Clin. Chem. 2016, 62, 505-513. [CrossRef]

128. Xu, Y.; Qin, T.; Li, J.; Wang, X.; Gao, C.; Xu, C.; Hao, J.; Liu, J.; Gao, S.; Ren, H. Detection of Circulating Tumor Cells Using Negative Enrichment Immunofluorescence and an In Situ Hybridization System in Pancreatic Cancer. Int. J. Mol. Sci. 2017, 18, 622. [CrossRef]

129. Bailey, P.; Chang, D.K.; Nones, K.; Johns, A.L.; Patch, A.M.; Gingras, M.C.; Miller, D.K.; Christ, A.N.; Bruxner, T.J.C.; Quinn, M.C.; et al. Genomic analyses identify molecular subtypes of pancreatic cancer. Nature 2016, 531, 47-52. [CrossRef]

130. Kulemann, B.; Rösch, S.; Seifert, S.; Timme, S.; Seifert, G.; Martini, V.; Kuvendjiska, J.; Glatz, T. Pancreatic cancer: Circulating Tumor Cells and Primary Tumors show Heterogeneous KRAS Mutations. Sci. Rep. 2017, 7, 4510. [CrossRef]

131. Chan-Seng-Yue, M.; Kim, J.C.; Wilson, G.W.; Ng, K.; Figueroa, E.F.; O'Kane, G.M.; Connor, A.A.; Denroche, R.E.; Grant, R.C.; McLeod, J.; et al. Transcription phenotypes of pancreatic cancer are driven by genomic events during tumor evolution. Nat. Genet. 2020, 52, 231-240. [CrossRef] [PubMed]

132. Yu, K.H.; Ricigliano, M.; McCarthy, B.; Chou, J.F.; Capanu, M.; Cooper, B.; Bartlett, A.; Covington, C.; Lowery, M.A.; O'reilly, E.M. Circulating tumor and invasive cell gene expression profile predicts treatment response and survival in pancreatic adenocarcinoma. Cancers 2018, 10, 467. [CrossRef] [PubMed]

133. Yu, J.; Gemenetzis, G.; Kinny-Koster, B.; Habib, J.R.; Groot, V.P.; Teinor, J.; Yin, L.; Pu, N.; Hasanain, A.; van Oosten, F.; et al. Pancreatic circulating tumor cell detection by targeted single-cell next-generation sequencing. Cancer Lett. 2020, 493, 245-253. [CrossRef]

134. Botrus, G.; Kosirorek, H.; Sonbol, M.B.; Kusne, Y.; Uson Junior, P.L.S.; Borad, M.J.; Ahn, D.H.; Kasi, P.M.; Drusbosky, L.M.; Dada, H.; et al. Circulating Tumor DNA-Based Testing and Actionable Findings in Patients with Advanced and Metastatic Pancreatic Adenocarcinoma. Oncologist 2021, 26, 569-578. [CrossRef] [PubMed]

135. Ignatiadis, M.; Sledge, G.W.; Jeffrey, S.S. Liquid biopsy enters the clinic-Implementation issues and future challenges. Nat. Rev. Clin. Oncol. 2021, 18, 297-312. [CrossRef] [PubMed]

136. Ericson, N.G.; Kapoor, V.; Liu, G.; Clein, A.C.; Sabath, D.E.; Kaldjian, E.P.; George, T. Abstract 5363: A direct amplicon-based targeted sequencing assay for mutation analysis of single circulating tumor cells and correlation with circulating tumor DNA. Cancer Res. 2020, 80, 5363.

137. Kolostova, K.; Broul, M.; Schraml, J.; Cegan, M.; Matkowski, R.; Fiutowski, M.; Bobek, V. Circulating tumor cells in localized prostate cancer: Isolation, cultivation in vitro and relationship to T-stage and Gleason score. Anticancer Res. 2014, 34, 3641-3646.

138. Yu, M.; Bardia, A.; Aceto, N.; Bersani, F.; Madden, M.W.; Donaldson, M.C.; Desai, R.; Zhu, H.; Comaills, V.; Zheng, Z.; et al. Ex vivo culture of circulating breast tumor cells for individualized testing of drug susceptibility. Science 2014, 345, 216-220. [CrossRef]

139. Zhang, Z.; Shiratsuchi, H.; Lin, J.; Chen, G.; Reddy, R.M.; Azizi, E.; Fouladdel, S.; Chang, A.C.; Lin, L.; Jiang, H.; et al. Expansion of CTCs from early stage lung cancer patients using a microfluidic co-culture model. Oncotarget 2014, 5, 12383-12397. [CrossRef]

140. Hodgkinson, C.L.; Morrow, C.J.; Li, Y.; Metcalf, R.L.; Rothwell, D.G.; Trapani, F.; Polanski, R.; Burt, D.J.; Simpson, K.L.; Morris, K.; et al. Tumorigenicity and genetic profiling of circulating tumor cells in small-cell lung cancer. Nat. Med. 2014, 20, 897-903. [CrossRef]

141. Gao, D.; Vela, I.; Sboner, A.; Iaquinta, P.J.; Karthaus, W.R.; Gopalan, A.; Dowling, C.; Wanjala, J.N.; Undvall, E.A.; Arora, V.K.; et al. Organoid cultures derived from patients with advanced prostate cancer. Cell 2014, 159, 176-187. [CrossRef] [PubMed]

142. Gach, P.C.; Attayek, P.J.; Whittlesey, R.L.; Yeh, J.J.; Allbritton, N.L. Micropallet arrays for the capture, isolation and culture of circulating tumor cells from whole blood of mice engrafted with primary human pancreatic adenocarcinoma. Biosens. Bioelectron. 2014, 54, 476-483. [CrossRef] [PubMed]

143. Arnoletti, J.P.; Fanaian, N.; Reza, J.; Sause, R.; Almodovar, A.J.; Srivastava, M.; Patel, S.; Veldhuis, P.P.; Griffith, E.; Shao, Y.P.; et al Pancreatic and bile duct cancer circulating tumor cells (CTC) form immune-resistant multi-cell type clusters in the portal venous circulation. Cancer Biol. 2018, 19, 887-897. [CrossRef] [PubMed] 
144. Zhu, Z.; Achreja, A.; Meurs, N.; Animasahun, O.; Owen, S.; Mittal, A.; Parikh, P.; Lo, T.W.; Franco-Barraza, J.; Shi, J.; et al. Tumour-reprogrammed stromal BCAT1 fuels branched-chain ketoacid dependency in stromal-rich PDAC tumours. Nat. Metab. 2020, 2, 775-792. [CrossRef]

145. Tiriac, H.; Bucobo, J.C.; Tzimas, D.; Grewel, S.; Lacomb, J.F.; Rowehl, L.M.; Nagula, S.; Wu, M.; Kim, J.; Sasson, A.; et al. Successful creation of pancreatic cancer organoids by means of EUS-guided fine-needle biopsy sampling for personalized cancer treatment. Gastrointest. Endosc. 2018, 87, 1474-1480. [CrossRef]

146. Seppala, T.T.; Zimmerman, J.W.; Sereni, E.; Plenker, D.; Suri, R.; Rozich, N.; Blair, A.; Thomas, D.L., 2nd; Teinor, J.; Javed, A.; et al. Patient-derived Organoid Pharmacotyping is a Clinically Tractable Strategy for Precision Medicine in Pancreatic Cancer. Ann. Surg. 2020, 272, 427-435. [CrossRef] 